УДК 633/635:655.056(075.8)

(C) 2014

Шевніков М. Я., доктор сільськогосподарських наук, Міленко О. Г., Лотиш І. I., аспіранти

(науковий керівник - доктор сільськогосподарських наук М. Я. Шевніков)

Полтавська державна аграрна академія

\title{
ЯКІСНІ ПОКАЗНИКИ НАСІННЯ СОЇ ЗАЛЕЖНО ВІД ВПЛИВУ МІНЕРАЛЬНИХ І БАКТЕРІАЛЬНИХ ДОБРИВ
}

Висвітлено вплив мінерального азоту та «Ризоторфіну» на накопичення білку та жиру в насінні сої. Інокуляція насіння «Ризоторфіном» та внесення мінеральних добрив, особливо сумісне їх застосування, сприяло значному підвищенню вмісту в насінні білка та зменшенню вмісту жиру. Бактеріальні добрива позитивно впливали на збільшення вмісту жиру у насінні сої - 18,1\%, але більш раціональною була комплексна дія мінеральних та бактеріальних добрив, які підвищували вміст жиру в сухій речовині насіння до $21,4-22,4 \%$.

Ключові слова: соя, мінеральні добрива, «Ризоторфін», білок, жир.

Постановка проблеми. Проблема біологічного азоту була і залишається актуальною в землеробстві. Особливо значна його роль в умовах погіршення екологічної ситуації та дороговизни азотних добрив. Екологічна доцільність використання процесу біологічної азотфіксації в господарських цілях сьогодні є одним із основних напрямів сучасного землеробства. Використання мінеральних добрив (передусім азотних) під сою $є$ спірним, оскільки ця культура спроможна за сприятливих умов засвоювати значну кількість азоту 3 повітря завдяки симбіозу з бульбочковими бактеріями. Молекулярний азот вони фіксують у симбіозі $з$ бобовими рослинами. Протиріччя у питанні азотного живлення пов'язані з особливостями біології сої, а також із тих причин, що досліди проводилися на грунтах різної окультуреності, з неоднаковим їх фізико-хімічним складом та грунтово-кліматичними умовами різних зон вирощування.

Аналіз основних досліджень і публікацій, у яких започатковано розв'язання проблеми. Соя досить вимоглива культура до поживного режиму грунту. На утворення 1 ц зерна соя виносить із грунту 7,5-10 кг азоту, 3-4,5 кг калію, 1,72,5 кг фосфору, тому вона добре реагує на органічні й мінеральні добрива у легкодоступній формі [6]. 3 урожайністю 25 ц/га соя виносить із грунту близько 200 кг азоту, 60 кг фосфору, 60-90 кг калію. Потреба в азоті на 60 \% задовольняється за рахунок його біологічної фіксації з повітря [5].
Як зернобобова культура соя здатна до симбіозу з бульбочковими бактеріями. Завдяки цьому у біологічний кругообіг вводиться величезна кількість атмосферного азоту. Біологічно зв'язаний азот може становити до 60-70 \% загального азоту врожаю, крім того значна його кількість залишається в грунті, що робить сою цінним попередником для наступних культур сівозміни [10].

У результаті симбіозу між бактеріями і соєю підвищується не тільки врожайність зерна, але й поліпшується якість врожаю - збільшується вміст білка, жиру, вітамінів тощо [2]. Ріст і розвиток цієї культури може проходити без внесення азотних добрив, так як симбіоз рослин з азотфіксуючими бактеріями забезпечує їх нормальне живлення та високу врожайність.

Для зернобобових культур неабияке значення для формування врожаю мають умови грунтового живлення рослин азотом. Потреба сої в поживних речовинах визначається іiі біологічними особливостями. На початку вегетації вона розвивається вкрай повільно, від сходів до цвітіння використовує незначну кількість поживних речовин. Найбільша потреба сої в елементах живлення спостерігалася в період «цвітіння-наливання бобів», поглинаючи в цей час близько 65-70 \% азоту, фосфору і калію [9].

Питання азотного живлення сої $є$ найбільш складним і дискусійним. Як ми вже відмічали, за сприятливих умов симбіозу мінеральні добрива за великого діапазону доз не підвищують врожайність сої, а інколи навіть ії знижують [10-12]. На Армавірській дослідній станції ВНДІОК приріст врожайності сої від інокуляції насіння за п'ять років дослідження становив 0,24 т/га, від внесення мінеральних добрив - 0,07-0,08 т/га. Сумісна дія інокуляції та мінеральних добрив дала отримання приросту врожайності сої в межах впливу однієї інокуляції, становивши 0,230,25 т/га [14].

Проблема біологічного азоту була й залишається актуальною в землеробстві. Особливо велика його роль в умовах погіршення екологічної ситуації та недостатнього забезпечення сільсько- 


\section{СІЛЬСЬКЕ ГОСПОДАРСТВО. РОСЛИННИЦТВО}

го господарства азотними добривами. Екологічна доцільність використання процесу біологічної азотфіксації в господарських цілях нині є одним iз основних напрямів сучасного землеробства. Такий підхід знаходить своє технологічне застосування у вирощуванні зернобобових культур, i в тому числі сої [8].

Використання мінеральних добрив, особливо азотних, під сою є спірним, оскільки ця культура спроможна за сприятливих умов засвоювати значну кількість азоту з повітря завдяки симбіозу 3 бульбочковими бактеріями. Молекулярний азот вони фіксують у симбіозі з бобовими рослинами. 3 цього приводу К. А. Тімірязєв писав, що відкриття факту можливості живлення рослин вільним азотом повітря - одне 3 найвидатніших надбань науки дев'ятнадцятого століття [6]. Протиріччя у питанні азотного живлення пов'язані 3 особливостями біології сої, та тим, що досліди проводилися на грунтах різної окультуреності, 3 неоднаковим їх фізико-хімічним складом і грунтово-кліматичними умовами різних зон вирощування [1, 3, 4, 7].

Отже, соя формує підвищений урожай в основному за рахунок симбіотичного азоту за раннього утворення бульбочок і високоефективному симбіозі. Кількість азоту, необхідна для підтримання росту і розвитку рослин до включення в процес азотфіксації, невелика й може бути забезпечена його грунтовими запасами. Не виключена роль стартових доз азотних добрив, особливо на бідних грунтах, для страхування рослин від можливої нестачі азоту на випадок затримки появи бульбочкових, повільного їх розвитку за несприятливих умов. Враховуючи те, що наявність азоту аміачної форми в рослинах пов'язана 3 азотфіксацією й споживанням азоту з грунту, а вміст нітратного азоту - виключно $з$ мінерального живлення, зниження відношення аміачного азоту до нітратного вказує на зменшення частки симбіотичного азоту в живленні сої за внесення азотних добрив.

Мета досліджень та методика їх проведення. Метою досліджень було встановити вплив мінерального азоту на фоні фосфорно-калійних добрив і біопрепарату «Ризоторфін» на якісні покаЗники насіння сої. Протягом 2011-2013 рр. нами проведено вивчення впливу мінеральних добрив та інокуляції на формування врожаю сої. Грунт дослідної ділянки - темно-сірий опідзолений iз наступними агрохімічними показниками: вміст гумусу (за Тюріним) - 2,5 \%; гідролітична кислотність (за Каппеном) - 1,9 мг-екв./100 г грунту; $\mathrm{pH}$ (сольове) - 5,9; азот (за Корнфілдом) 4,49; фосфор (за Чириковим) - 12,0; обмінний калій - 16,0 мг/100 г грунту. До схеми досліду включені варіанти: 1) Без добрив (контроль), 2) «Ризоторфін», 3) $\left.\mathrm{N}_{30}, 4\right) \mathrm{N}_{60}$, 5) $\mathrm{P}_{60}$, 6) $\mathrm{N}_{30} \mathrm{P}_{60}$, 7) $\left.\mathrm{N}_{60} \mathrm{P}_{60}, 8\right) \mathrm{N}_{30}+$ «Ризоторфін», 9) $\mathrm{N}_{60} \mathrm{P}_{60}+$ «Ризоторфін», 10) $\mathrm{N}_{60} \mathrm{P}_{60}+$ «Ризоторфін». Фосфорні добрива вносили під основний обробіток грунту; азотні - навесні під культивацію перед сівбою. «Ризоторфіном» насіння обробляли в день сівби. Сорт сої - Білосніжка. Технологія вирощування сої - загальноприйнята для зони лісостепу. Повторність у досліді - чотириразова. Метеорологічні умови в роки проведення досліджень були близькими до середніх багаторічних. Попередник пшениця озима. Площа посівної ділянки - $25 \mathrm{~m}^{2}$,

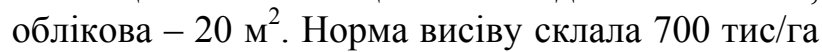
схожих насінин. Спосіб сівби - широкорядний із міжряддями 45 см. Збирання врожаю здійснювали прямим комбайнуванням.

Результати досліджень. Соя характеризується відносно помірними темпами накопичення сухої речовини і засвоєння азоту на ранніх стадіях онтогенезу. Високу інтенсивність вказаних процесів спостерігали в період утворення та формування бобів. Аналізуючи динаміку засвоєння азоту рослинами протягом вегетації, відмічено суттєву роль внесених азотних добрив у загальний азотний баланс рослин. Враховуючи той факт, що засвоєння соєю мінерального азоту уповільнюється на час цвітіння, то в період підвищеної ії потреби в азоті єдиним його джерелом був процес симбіотичної азотфіксації, що проходив досить інтенсивно. Високі темпи азотфіксації в період репродуктивної фази підтримувались за рахунок посилення активності одиниці маси бульбочок, пізніше - за рахунок збільшення їх маси. У період від початку плодоутворення до наливання насіння в рослини сої надійшло 50-60 \% азоту від загальної його кількості, фіксованого бульбочками за вегетаційний період. Тому ріст бобів і наливання зерна здійснювались, головним чином, шляхом безпосереднього використання фіксованого азоту і ні в якому разі не за рахунок реутилізації раніше накопиченого азоту, фіксованого бульбочками за вегетацію.

Дослідження біометричних показників вказують на позитивну дію мінеральних добрив та ризоторфіну на основні елементи структури врожаю рослин. Втрати врожаю насіння під час збирання визначаються, в значній мірі, висотою прикріплення нижніх бобів. Цей показник був найнижчим на ділянках без внесення добрив 17,7 см, за внесення добрив висота прикріплення нижніх бобів була вищою і складала 18,2-22,8 cм, або на 3,0-28,8 \% більше неудобрених ділянок (табл. 1). 
СІЛЬСЬКЕ ГОСПОДАРСТВО. РОСЛИННИЦТВО

\section{1. Вилив мінеральних добрив та обробки насіння «Ризоторфіном» на структуру рослин сої (середнс за 2011-2013 рр.)}

\begin{tabular}{|c|c|c|c|c|c|c|c|}
\hline \multirow[b]{2}{*}{ Варіанти } & \multicolumn{2}{|c|}{ Висота рослин, см } & \multicolumn{3}{|c|}{ Кількість на одну рослину } & \multirow{2}{*}{$\begin{array}{c}\text { Маса на- } \\
\text { сіння } 3 \\
\text { однієї рос- } \\
\text { лини, Г }\end{array}$} & \multirow[b]{2}{*}{$\begin{array}{l}\text { Маса } 1000 \\
\text { насінин, г }\end{array}$} \\
\hline & загальна & $\begin{array}{l}\text { прикріплення } \\
\text { нижніх бобів }\end{array}$ & гілок & бобів & насінин & & \\
\hline 1. Без добрив & 90,5 & 13,7 & 1,7 & 21,7 & 39 & 5,41 & 139 \\
\hline 2. «Ризоторфін» & 92,0 & 15,1 & 1,9 & 23,0 & 41,9 & 5,91 & 141 \\
\hline 3. $\mathrm{N}_{30}$ & 94,9 & 17,6 & 1,6 & 23,1 & 41,8 & 6,04 & 145 \\
\hline 4. $\mathrm{N}_{60}$ & 95,4 & 17,9 & 1,8 & 24,9 & 42,4 & 6,82 & 150 \\
\hline 5. $\mathrm{P}_{60}$ & 91,2 & 14,6 & 1,7 & 20,8 & 39,8 & 7,07 & 148 \\
\hline 6. $\mathrm{N}_{30} \mathrm{P}_{60}$ & 95,3 & 17,9 & 1,9 & 23,4 & 50,3 & 7,40 & 149 \\
\hline 7. $\mathrm{N}_{60} \mathrm{P}_{60}$ & 96,7 & 18,4 & 2,0 & 24,1 & 52,3 & 7,68 & 147 \\
\hline 8. $\mathrm{P}_{60}+$ «Ризоторфін» & 97,8 & 17,4 & 1,8 & 23,9 & 50,2 & 7,42 & 148 \\
\hline 9. $\mathrm{N}_{30} \mathrm{P}_{60}+$ «Ризоторфін» & 99,2 & 18,4 & 2,1 & 24,3 & 55,6 & 7,92 & 144 \\
\hline 10. $\mathrm{N}_{60} \mathrm{P}_{60}+$ «Ризоторфін» & 99,6 & 18,8 & 2,2 & 25,1 & 55,3 & 8,02 & 145 \\
\hline $\mathrm{HIP}_{05}$ & 4,8 & 1,2 & 0,11 & 1,4 & 2,7 & 0,32 & 7,4 \\
\hline
\end{tabular}

Реакція рослин на умови вирощування відображується, в першу чергу, на висоті рослин. Ростові процеси визначають у значній мірі продуктивність рослин, так як вони зв'язані з наростанням листкової поверхні, накопиченням надземної маси. Загальна висота рослин на удобрених ділянках, а також на ділянках із висівом інокульованим насінням була вищою - 91,2-99,6 см (без внесення добрив - 90,5 см). Щодо інших показників структури, то за внесення $\mathrm{N}_{30} \mathrm{P}_{60}$ та обробці насіння «Ризоторфіном» кількість гілок на одній рослині становила 2,1 , кількість бобів - 24,3, кількість насіння - 55,6, маса насіння з однієї рослини $-7,99$ грамів. Маса 1000 насінин у значній мірі залежала від співвідношення кількості бобів та насіння на одній рослині: більшою вона була на удобрених ділянках і коливалася залежно від дози добрив та обробки насіння «Ризоторфіном» у межах 141-150 г (без внесення добрив - 139 г).

Застосування мінеральних добрив та «Ризоторфіну» спричинило зміну не тільки врожайності, але й вплинуло на якість насіння сої. Для вивчення якості сухої речовини визначали вміст білка та жиру (табл. 2). Характер впливу природно-кліматичних факторів на вміст білку і жиру був незначним, оскільки їх склад по роках не досить відрізнявся.

Інокуляція насіння «Ризоторфіном» та внесення мінеральних добрив, особливо сумісне їх застосування, спричинило значне підвищення вмісту в насінні білка та зменшення вмісту жиру. У середньому за три роки досліджень вміст у сухій речовині білка без внесення добрив склав $31,1 \%$, за обробки насіння «Ризоторфіном» 32,7 , за внесення $\mathrm{N}_{30} \mathrm{P}_{60}$ та обробці насіння «Ри- зоторфіном» - 37,0 \%. На всіх інших ділянках досліду з різними дозами мінеральних та бактеріальних добрив коливання вмісту білка в сухій речовині мало проміжний характер. Вплив погодних умов на характер накопичення білка в сухій речовині насіння був незначним, так як не спостерігалось його коливання у різні роки досліджень. Характер розподілу вмісту жиру в сухій речовині насіння сої був ідентичним розподілу білка. Відмінність лише в тому, що азотні добрива не мали суттєвого впливу на збільшення вмісту жиру, так як більш суттєвий влив здійснювали фосфорні добрива. В середньому за три роки досліджень вміст жиру у насінні сої за внесення азотних добрив склав 17,6-18,2 \%, $\mathrm{P}_{60}-18,7$ (без добрив - 17,2 \%). Бактеріальні добрива позитивно впливали на збільшення вмісту жиру у насінні сої, вміст якого склав $18,1 \%$. Однак найбільш раціональною була комплексна дія мінеральних і бактеріальних добрив, які підвищували вміст жиру в сухій речовині насіння до 21,4$22,4 \%$. Зміна хімічного складу насіння сої була сприятливою для підвищення загального збору білка та жиру. Одностороннє застосування азоту або фосфору у вигляді добрива спричинило незначне підвищення загального збору білка і жиру в насінні. Більш доцільним було застосування «Ризоторфіну», або азотно-фосфорних добрив, так як у даному випадку отримали приріст збору білка 34-42 \%, жиру - 34-37\% (табл. 3). Комплексне застосування «Ризоторфіну» та добрив у дозі $\mathrm{N}_{30} \mathrm{P}_{60}$ було найефективнішим: збір білка становив 0,83 т/га, жиру - 0,46 т/га, що на 47- $53 \%$ вище, ніж без застосування добрив. 
СІЛЬСЬКЕ ГОСПОДАРСТВО. РОСЛИННИЦТВО

\section{2. Вплив мінеральних добрив та інокуляції насіння сої на вміст білка та жиру в сой залежно від внесення мінеральних добрив та інокуляції}

\begin{tabular}{|c|c|c|c|c|c|c|c|c|}
\hline \multirow{3}{*}{ Варіанти } & \multicolumn{8}{|c|}{ Вміст в сухій речовині, \% } \\
\hline & \multicolumn{4}{|c|}{ білок } & \multicolumn{4}{|c|}{ жир } \\
\hline & $2011 \mathrm{p}$. & $2012 \mathrm{p}$. & $2013 \mathrm{p}$. & середнє & $2011 \mathrm{p}$. & $2012 \mathrm{p}$. & $2013 \mathrm{p}$. & середнє \\
\hline 1. Без добрив & 32,7 & 30,6 & 30,1 & 31,1 & 17,5 & 17,3 & 17,1 & 17,2 \\
\hline 2. «Ризоторфін» & 33,2 & 31,4 & 33,4 & 32,7 & 18,1 & 18,0 & 18,1 & 18,1 \\
\hline 3. $\mathrm{N}_{30}$ & 33,6 & 32,6 & 30,6 & 32,3 & 17,9 & 17,5 & 17,4 & 17,6 \\
\hline 4. $\mathrm{N}_{60}$ & 35,0 & 36,0 & 34,1 & 35,0 & 18,2 & 18,4 & 18,1 & 18,2 \\
\hline 5. $\mathrm{P}_{60}$ & 33,0 & 33,2 & 32,1 & 32,8 & 18,2 & 18,5 & 19,4 & 18,7 \\
\hline 6. $\mathrm{N}_{30} \mathrm{P}_{60}$ & 35,8 & 36,1 & 35,0 & 35,6 & 19,6 & 20,0 & 19,8 & 19,8 \\
\hline 7. $\mathrm{N}_{60} \mathrm{P}_{60}$ & 35,8 & 36,8 & 36,4 & 36,3 & 19,9 & 19,7 & 19,0 & 19,5 \\
\hline 8. $\mathrm{P}_{60}+$ «Ризоторфін» & 36,8 & 36,6 & 35,0 & 36,5 & 20,5 & 20,1 & 20,5 & 20,4 \\
\hline $\begin{array}{c}9 . \mathrm{N}_{30} \mathrm{P}_{60}+ \\
\text { «Ризоторфін» }\end{array}$ & 36,2 & 37,4 & 37,4 & 37,0 & 20,6 & 21,4 & 21,3 & 21,4 \\
\hline $\begin{array}{c}10 . \mathrm{N}_{60} \mathrm{P}_{60}+ \\
\text { «Ризоторфін» }\end{array}$ & 36,6 & 36,8 & 36,6 & 36,6 & 22,2 & 22,6 & 22,6 & 22,4 \\
\hline $\mathrm{HIP}_{0,5} \%$ & 1,2 & 0,9 & 1,3 & & 0,7 & 0,6 & 0,8 & \\
\hline
\end{tabular}

\section{3. Вилив мінеральних добрив та інокуляцї̈ на збір білка і жиру в насінні сої} (середне за 2011-2013 рp.)

\begin{tabular}{|c|c|c|c|c|c|c|}
\hline \multirow{3}{*}{ Варіанти } & \multicolumn{3}{|c|}{ Білок } & \multicolumn{3}{|c|}{ Жир } \\
\hline & \multirow{2}{*}{$\begin{array}{c}\text { збір, } \\
\text { т/га }\end{array}$} & \multicolumn{2}{|c|}{ приріст } & \multirow{2}{*}{$\begin{array}{c}\text { Збір, } \\
\text { т/га }\end{array}$} & \multicolumn{2}{|c|}{ приріст } \\
\hline & & т/га & $\%$ & & т/га & $\%$ \\
\hline 1. Без добрив & 0,54 & - & - & 0,30 & - & - \\
\hline 2. «Ризоторфін» & 0,63 & 0,07 & 16,0 & 0,35 & 0,048 & 15,9 \\
\hline 3. $\mathrm{N}_{30}$ & 0,60 & 0,06 & 10,2 & 0,33 & 0,026 & 8,7 \\
\hline 4. $\mathrm{N}_{60}$ & 0,67 & 0,13 & 22,8 & 0,35 & 0,046 & 15,3 \\
\hline 5. $\mathrm{P}_{60}$ & 0,60 & 0,06 & 11,0 & 0,32 & 0,021 & 7,0 \\
\hline 6. $\mathrm{N}_{30} \mathrm{P}_{60}$ & 0,70 & 0,16 & 34,0 & 0,41 & 0,104 & 34,5 \\
\hline 7. $\mathrm{N}_{60} \mathrm{P}_{60}$ & 0,77 & 0,23 & 42,0 & 0,42 & 0,114 & 37,8 \\
\hline 8. $\mathrm{P}_{60}+$ «Ризоторфін» & 0,77 & 0,23 & 41,7 & 0,43 & 0,131 & 43,5 \\
\hline 9. $\mathrm{N}_{30} \mathrm{P}_{60}+$ «Ризоторфін» & 0,83 & 0,29 & 53,6 & 0,46 & 0,160 & 53,1 \\
\hline $\begin{array}{c}\text { 10. } \mathrm{N}_{60} \mathrm{P}_{60}+ \\
\text { «Ризоторфін» }\end{array}$ & 0,81 & 0,27 & 47,9 & 0,47 & 0,171 & 56,8 \\
\hline $\mathrm{HIP}_{0,5}$ & 0,04 & & & 0,02 & & \\
\hline
\end{tabular}

Не дивлячись на високу енергоємність процесу симбіотичної азотфіксації, величезну потребу рослин сої в продуктах фотосинтезу і конкуренцію їх із бульбочками за його продукти, соя здатна навіть у період утворення плодів підтримувати активне функціонування фіксуючої азот симбіотичної системи. За внесення азотних добрив або обробки насіння «Ризоторфіном» підтримувався нормальних хід формування бобів та інтенсивне накопичення в них білку. Мабуть, підвищена потреба сої в достатньому забезпеченні азотом у період росту й формування генеративних органів є важливим фактором, який визначає на рівні цілої рослини високі темпи азотфіксації в репродуктивний період.

Аналізуючи характер формування врожаю сої за внесення азотних добрив та інокуляції окремо, спостерігаємо, що на етапі переходу рослин від використання фіксованого азоту у вигляді єдиного його джерела було недостатнім для підтримання потреби іiі в азоті. Темпи накопичення сухої речовини й азоту тимчасово знижувались, а позитивна дія більшої дози азоту $\left(\mathrm{N}_{60}\right)$ на ріст рослин втрачалася. Не виключено, що причиною 


\section{СІЛЬСЬКЕ ГОСПОДАРСТВО. РОСЛИННИЦТВО}

відсутності дії високих доз азотних добрив може бути тимчасове погіршення використання азоту в період їх адаптації до переваги використання симбіотично фіксованого азоту.

\section{Висновки:}

1. Соя здатна тривалий період підтримувати активне функціонування фіксуючої азот симбіотичної системи. За інокуляції насіння «Ризоторфіном» та внесенні добрив у дозі $\mathrm{N}_{30} \mathrm{P}_{60}$ в період цвітіння, плодоутворення та наливання зерна підтримувався нормальний хід формування бобів та інтенсивне накопичення в них білка.

2. Підвищена потреба бобів у азоті в період

\section{БІБЛІОГРАФІЯ}

1. Арсений $A$. А. Влияние норм высева, удобрений и орошения на продуктивность сои / А. А. Арсений, Г. А. Тодиев. - Кишинев, 1977. C. 32-36.

2. Бабич А. О., Бабич-Побережна А. А. Селекція і розміщення виробництва сої в Україні / А. О. Бабич, А. А. Бабич-Побережна - К. : ФОП Данилюк В. Г., 2008. - 216 с. - (Монографія).

3. Даценко О. В. Про дію молібдену та бору на нагромадження вегетативної маси, урожай і нітрогеназну активність сої / О. В. Даценко. - Чабани, 1994. - 8 [1] с. - (Наукові основи ведення сільського господарства України в сучасних умовах).

4. Заверюхин В. И. Соя на орошаемых землях / В. И. Заверюхин // Зерновое хазяйство. - 1977. №6. - С. 45-46.

5. Зінченко О. I. Біологічне рослинництво : навч. пос. [для студ. вищ. навч. закл.] / О. І. Зінченко, О. С. Алексеєва, П. М. Приходько. - К. : Вища школа, 1996. - 139 с.

6. Зінченко О. I. Рослинництво : підруч. [для студ. вищ. навч. закл.] / О. І. Зінченко, В. Н. Салатенко, М. А. Білоножко. - К. : Аграрна освіта, 2001. $-591 \mathrm{c}$.

7. Котенко И. Т. Влияние минеральных удобрений на урожайность сои при орошении / И. Т. Котенко // Химия в сельском хозяйстве. - росту та формування є важливим фактором, який визначає на рівні цілої рослини високі темпи азотфіксації в бульбочках сої у репродуктивний період. Вміст жиру у насінні сої за внесення азотних добрив становив 17,6-18,2 \%, $\mathrm{P}_{60}-18,7$ (без добрив $-17,2 \%$ ).

3. Бактеріальні добрива позитивно впливали на збільшення вмісту жиру у насінні сої, вміст якого склав 18,1%. Однак найбільш раціональною була комплексна дія мінеральних та бактеріальних добрив, які підвищували вміст жиру в сухій речовині насіння до 21,4-22,4 \%.

1988. - №3. - C. 18-20.

8. Патика В. П. Напрями і координація наукових досліджень $з$ грунтової мікробіології / В. П. Патика // Вісник аграрної науки. - 1996. - №6. - С. 5-10.

9. Самошкин В. И. Ризоторфин под сою / В. И. Самошкин, Н. 3. Толкачев // Масличные культуры. - 1982. - №2. - С. 25-26.

10. Самошкин В. И. Эффективность гаммаризоторфина на посевах сои в Крыму / В. И. Самошкин, Н. 3. Толкачев // Бюл. ВНИИСХ микробиологии. - 1981. - №34. - С. 34-36.

11. Сварадж Л. Действие темноты на симбиотическую азотофиксацию у сои / [Л. Сварадж, П. Н. Дуброво, С. В. Ищенко и др.] // Физиология растений. - 1995. - №3. - С. 480-487.

12. Сварадж Л., Мищенко С. В., Козлова Г. И. $u \partial p$. Действие водного дефицита на симбиотическую азотофиксацию у сои / [Л. Сварадж, С. В. Мищенко, Г. И. Козлова и др. ] // Физиология растений. - 1984. - №5. - С. 833-840.

13. Тимирязев K. А. Солнце, жизнь и хлорофилл / Тимирязев К. А. - М. : Сельхозгиз, 1957. С. 60-62. - (Избр. соч.; т. 1).

14. Цветкова М. А. Действие минеральных и бактериальных удобрений при орошении на урожай и качество зерна сои / М. А. Цветкова, Р. А. Термеева // Химия в сельском хозяйстве. 1983. - №3. - С. 20-22. 